\title{
EVALUASI LITERATUR DENGAN MENGGUNAKAN ANALISIS SITIRAN TERHADAP SKRIPSI JURUSAN MANAJEMEN HUTAN TAHUN 2008 DI PERPUSTAKAAN FAKULTAS KEHUTANAN. UGM
}

\author{
Isbandini \\ Perpustakaan Universitas Gadjah Mada \\ dien_nick@yahoo.com
}

\begin{abstract}
The purpose of this research is : (1) to know the literature obsolescence cited in the 2008 theses at the Department of Forest Management, Faculty of Forestry UGM (2) to know the growth of literature based on the type and language of collection which were mostly cited by students at the Department of Forest Management, Faculty of Forestry UGM in writing theses during 2008, (3) to know the availability of a collection cited by students of the Department of Forest Management, Faculty of Forestry Gadjah Mada University in writing theses in 2008. This study is a descriptive research, of which the subject is the theses at the Department of Forest Management, Faculty of Forestry Gadjah Mada University in 2008 which amounted to 67 theses and research objects is all the literature included in the cited bibliography on Forest Management theses, Faculty of Forestry Gadjah Mada University in 2008 as many as 1498 titles. Method of data collection uses documentation. Data analysis uses citation analysis. The results show that: (1) the literature obsolescence of the theses aged 8 years or less is considered up to date and aged more than 8 years is out of date (2) the growth of literature on this research shows 8 years; this means that the growth of Forest Management literature is relatively quick compared to other subjects, while the growth of the literature based on literature and language of the literature indicates that books are most widely cited numbering as many as 950 citations (63.42\%), the language of literature most widely cited is Indonesian, comprising 1328 citations (88.65\%), (3) overall citation data in this study were 865 citations or $57.74 \%$ cited in the literature on theses writing were available at the library; and as many as 633 or $42.26 \%$ are not available in the library.
\end{abstract}

\section{Keywords : citation analysis, halflife literature, obsolescence literature}

\section{Abstrak}

Penelitian ini bertujuan untuk : (1) mengetahui keusangan literatur yang disitir pada skripsi Jurusan Manajemen Hutan Fakultas Kehutanan UGM tahun 2008 (2) mengetahui pertumbuhan literatur berdasarkan jenis koleksi dan bahasa koleksi yang banyak disitir oleh mahasiswa Jurusan Manajemen Hutan Fakultas Kehutanan UGM dalam pembuatan skripsi tahun 2008, (3) mengetahui ketersediaan koleksi yang disitir oleh mahasiswa Jurusan Manajemen Hutan Fakultas Kehutanan UGM dalam pembuatan skripsi tahun 2008, Penelitian ini merupakan penelitian deskriptif, dengan subjek penelitian adalah skripsi Jurusan Manajemen Hutan Fakultas Kehutanan UGM tahun 2008 yang berjumlah 67 skripsidan objek penelitian adalah semua literatur yang disitir yang dicantumkan dalam daftar pustaka pada skripsi Jurusan Manajemen Hutan Fakultas Kehutanan UGM tahun 2008 yang berjumlah 1498. Metode pengumpulan data menggunakan metode dokumentasi. Analisis data menggunakan analisis sitiran. Hasil penelitian menunjukkan bahwa : (1) keusangan literatur yang digunakan pada skripsi jurusan Manajemen Hutan Fakultas Kehutanan UGM tahun 2008 adalah literatur yang berusia kurang atau sama dengan 8 tahun dikatakan mutakhir, sedangkan literatur yang berusia lebih dari 8 tahun dikatakan sudah usang (2) pertumbuhan literatur pada penelitian ini menunjukkan 8 tahun, hal ini berarti bahwa pertumbuhan literatur bidang Manajemen Hutan cukup cepat jika dibandingkan dengan ilmu lain, sedangkan pertumbuhan berdasarkan jenis literatur dan bahasa literatur menunjukkan bahwa 
buku merupakan jenis literatur yang banyak disitir dengan 950 sitiran $(63,42 \%)$, bahasa literatur yang paling banyak disitir adalah literatur berbahasa Indonesia dengan 1.328 sitiran $(88,65 \%)$, (3) keseluruhan data sitiran dalam penelitian ini ditemukan 865 sitiran atau 57,74\% literatur yang disitir dalam penulisan skripsi tersedia di perpustakaan dan sebanyak 633 sitiran atau 42,26\% literatur yang disitir tidak tersedia di perpustakaan.

(Kata kunci : analisis sitiran, paro hidup literatur, keusangan literatur)

\section{PENDAHULUAN}

Pada dasarnya perpustakaan mengemban lima fungsi yaitu penyimpanan, pendidikan, penelitian, informasi dan rekreasi. Salah satu fungsi perpustakaan adalah fungsi penelitian. Perpustakaan berfungsi menyediakan berbagai macam koleksi (informasi) untuk keperluan penelitian yang dilakukan oleh pemakai (Qalyubi, 2007:16).

Salah satu kegiatan penelitian yang dilakukan di perguruan tinggi adalah penelitian untuk tugas akhir bagi program sarjana strata satu yang selanjutnya akan dituangkan dalam bentuk skripsi. Skripsi adalah suatu karya tulis ilmiah yang lebih bersifat memberikan gambaran atau diskripsi tentang sesuatu atau melukiskan kenyataan atau fakta berdasarkan hasil suatu riset (Jamasri, 2004:4).

Penulisan karya ilmiah tidak dapat lepas diri dari keharusan menggunakan berbagai sumber literatur bahan pustaka sebagai kutipan atau sitiran.Untuk itu dalam menyusun rencana penelitian peneliti membutuhkan dukungan berbagai macam sumber literatur yang relevan dengan bidang yang ditelitinya, baik dari literatur primer maupun dari literatur sekunder yang dihasilkan oleh peneliti lain sebagai data untuk memperoleh peluang untuk menghasilkan temuan baru. Artinya suatu dokumen memberi dukungan kepada dokumen yang lain dan sitasi suatu dokumen diterima oleh dokumen yang lain. Jadi ada hubungan antara bagian dengan keseluruhan dokumen yang dikutip.

Biasanya sumber literatur yang dikutip atau disitir dicantumkan pada daftar pustaka/daftar referensi setiap karya ilmiah atau dalam suatu terbitan. Sitiran digunakan penulis sebagai sandaran ilmiah untuk mengurangi subjektivitas sehingga tingkat objektivitasnya tinggi dan meningkatkan kualitas karya ilmiahnya. Literatur yang disitir dalam skripsi mahasiswa adalah literatur yang isinya terkait dengan subjek kajian skripsi yang ditulis. Kajian tentang hubungan ini disebut analisis sitiran/sitasi yang merupakan bagian dari bibliometrik. Sitiran adalah pernyataan yang diterima suatu dokumen dari dokumen lain. Sitiran mengarah pada karya yang disitasi yang dilakukan oleh penulis sesudah karya yang disitasi diterbitkan.

Mahasiswa berharap perpustakaan mampu menyediakan literatur pendukung yang diperlukan untuk kelancaran penelitian. Upaya yang dapat dilakukan untuk mengetahui literatur yang dibutuhkan pengguna adalah melalui kajian analisis sitiran terhadap karya tulis yang dihasilkan oleh pengguna perpustakaan.Jumlah sitiran dapat digunakan untuk menghitung paro hidup sebuah bidang ilmu. Paro hidup menunjukkan kecepatan pertumbuhan literatur, dengan sendirinya pertumbuhan ilmu, sehingga semakin muda usia paro hidup sebuah bidang ilmu, semakin cepat perkembangan ilmu tersebut (Sulistyo-Basuki, 2004:79). Dari analisis sitiran dapat dihasilkan mengenai gambaran kecepatan pertumbuhan literatur berdasarkan jenis literatur yang disitir, bahasa literatur yang disitir, ketersediaan koleksi yang disitir di perpustakaan serta paro hidup literatur yang disitir.

Berkaitan dengan penelitian ini, maka akan diteliti sitiran yang digunakan mahasiswa dalam penulisan skripsi, yang hasilnya dapat digunakan untuk mengetahui paro hidup literatur dan kecepatan pertumbuhan literatur bidang manajemen hutan Fakultas Kehutanan UGM.

Tujuan dari penelitian ini adalah :

1. Mengetahui keusangan literatur yang disitir pada skripsi Jurusan Manajemen Hutan Fakultas Kehutanan UGM tahun 2008.

2. Mengetahui pertumbuhan literatur berdasarkan:

a. Jenis koleksi yang banyak disitir oleh mahasiswa Jurusan Manajemen Hutan Fakultas Kehutanan UGM dalam pembuatan skripsi tahun 2008.

b. Bahasa koleksi yang banyak disitir oleh mahasiswa Jurusan Manajemen Hutan Fakultas Kehutanan UGM dalam pembuatan skripsi tahun 2008.

3. Mengetahui ketersediaan koleksi yang disitir oleh mahasiswa Jurusan Manajemen Hutan Fakultas Kehutanan UGM dalam pembuatan skripsi tahun 2008. 


\section{TINJAUAN PUSTAKA}

\section{Pengertian Koleksi}

Menurut Sulistyo-Basuki (1991:3), koleksi perpustakaan meliputi semua bahan cetak (buku, majalah, laporan, skripsi, tesis, disertasi, pamplet, prosiding, manuskrip (naskah), lembaran musik, berbagai karya media audio visual seperti film, slide, kaset, piringan hitam, bentuk mikro seperti mikrofilm, mikrofish dan mikroburam (microopaque).

\section{Pengembangan Koleksi Perpustakaan Perguruan Tinggi}

Menurut Rahayuningsih (2007:13) pengembangan koleksi adalah semua kegiatan untuk memperluas koleksi yang ada di perpustakaan, terutama kegiatan yang berkaitan dengan pemilihan dan pengadaan bahan pustaka. Pengembangan koleksi dilakukan untuk meningkatkan koleksi baik dari segi kuantitas maupun kualitas. Kuantitas mencakup banyaknya judul dan eksemplar, sedangkan kualitas mencakup tingkat baik buruknya sebuah koleksi ditinjau dari segi fisik, isi, kesesuaian dengan kebutuhan pemustaka.

Pengembangan koleksi merupakan proses memastikan bahwa kebutuhan informasi dari para pemakai akan terpenuhi secara tepat waktu dan tepat guna dengan memanfaatkan sumber-sumber informasi yang dihimpun oleh perpustakaan (Qalyubi, 2007:77).

\section{Evaluasi Koleksi}

Evaluasi koleksi adalah kegiatan menilai koleksi perpustakaan baik dari segi ketersediaan koleksi itu bagi pengguna maupun pemanfaatan koleksi itu oleh pengguna (Sujana, 2006:1).

Menurut Evans dan Zarnosky (2000:434), metode atau teknikmengevaluasi koleksi dikelompokkan menjadi dua, yaitu berfokuskankepada koleksi dan berfokuskan kepada penggunaan. Metode dan teknikyang berfokuskan kepada koleksi antara lain:1. Pengecekan daftar, bibliografi, dan katalog, 2. Opini ahli, 3. Perbandingan statistik penggunaan, 4. Standar koleksi. Sedangkan metode atau teknik yang befokuskan kepada penggunaanantara lain:1. Kajian sirkulasi, 2. Kajian opini pemakai, 3. Analisis statistik peminjaman antarperpustakaan, 4. Analisis sitiran, 5. Kajian penggunaan di dalam perpustakaan, 6. Ketersediaan koleksi di rak, 7. Kajian simulasi penggunaan, 8. Tes pengiriman dokumen

Penelitian ini menggunakan metode analisis sitiran dalammengevaluasi koleksi. Analisis sitiran relatif mudah dilakukan danmenyediakan pengukuran yang baik pada perubahan kekuatan koleksi sepanjang waktu (Evans, 2000: 446).

\section{Analisis sitiran}

Pada dasarnya analisis sitiran merupakan bagian dari bibliometrika. Sulistyo-Basuki (2002:4) menyebutkan bahwa pada dasarnya bibliometrika terbagi atas dua kelompok besar yaitu kelompok yang mengkaji distribusi publikasi dan kelompok yang membahas analisis sitiran/sitasi (citation analysis). Metode analisis sitiran merupakan salah satu teknik bibliometrika dalam ilmu perpustakaan dan informasi yang mengkaji hubungan antara dokumen yang menyitir dengan dokumen yang disitir.

Menurut Sulistyo-Basuki (2004:71) dalam kaitannya dengan sitiran, dikenal dua istilah ialah referencing atau perujukan dan citation atau sitiran. Referencing mengarah pada perujukan ke karya yang telah ada sebelumnya dan mengutip pengarang sebelumnya sedangkan citation mengarah pada karya yang diacu yang dilakukan oleh pengarang sesudah karya yang diacu diterbitkan. Sitiran merupakan sebuah hubungan antara dokumen yang dikutip dengan yang mengutip.

Analisis sitiran adalah kajian terhadap sejumlah sitiran atau rujukan yang terdapat dalam karya tulis ilmiah tertentu (Zulaikha, 2002:41). Sedangkan menurut Hartinah (2002:1) analisis sitiran adalah penyelidikan melalui data sitiran dari suatu dokumen, baik dokumen yang disitir maupun dokumen yang menyitir.

\section{Keusangan Literatur}

Menurut Hartinah (2002:1) Obsolescence atau literature aging atau keusangan literatur adalah penurunan dalam menggunakan suatu literatur atau kelompok literatur (pada suatu topik tertentu) pada suatu periode waktu karena literatur-literatur tersebut menjadi lebih tua. Kemudian menurut Hasugian (2005:4), keusangan informasi berarti bahwa informasi yang ada dalam sebuah dokumen semakin jarang digunakan, dengan kata lain penggunaan informasinya makin menurun dan akhirnya pada suatu saat tidak digunakan lagi.

Dalam bibliometrika, data sitiran dapat digunakan untuk mengukur keusangan (obsolescence) literatur. Menurut Hartinah (2002:2) ada dua tipe dasar keusangan (obsolescence) literatur yaitu: 
1. Obsolencence synchronous merupakan ukuran keusangan literatur dari sekelompok literatur dengan cara memeriksa tahun terbitan referensi literatur. Median citation age (median umur sitiran) termasuk dalam obsolécence synchronous.

2. Obsolencence diachronous adalah ukuran keusangan literatur dari sekelompok literatur dengan cara memeriksa tahun terbit dari sitiran yang diterima literatur tersebut. Half life atau paro hidup literatur adalah ukuran dari obsolescence diachronous

Paro hidup dalam literatur berarti usia dari separo literatur yang digunakan dalam sebuah bidang (Sulistyo-Basuki, 2004:79). Menurut Hartinah (2002: 2), paro hidup literatur (half life) sitiran adalah jangka waktu yang diperlukan oleh separuh literatur bidang tertentu yang disitir oleh literatur terakhir yang dipublikasikan. Dalam konteks perpustakaan, paro hidup dapat digunakan untuk mengetahui usia koleksi sehingga dapat digunakan sebagai bahan pertimbangan dalam menyiangi koleksi.

Męnurut Sulistyo-Basuki (2004:80) untuk menghitung paro hidup maka jumlah sitiran dibagi dalam kelompok 10 tahun, misalnya 0-10 tahun, 1120 tahun, 21-30 tahun dan seterusnya. Nilai umur paro dihitung dengan menetapkan tahun pada saat persentase kumulatif dari sitiran dapat mencapai jumlah yang sama atau lebih dari $50 \%$.

Paro hidup dapat dihitung dengan mengurutkan semua referensi yang diperlukan oleh semua dokumen pada masing-masing bidang mulai yang tertua (tahun terkecil) sampai yang terbaru (tahun terbesar) atau sebaliknya. Kemudian dicari median yang membagi daftar referensi yang sudah terurut tersebut menjadi 2 (dua) masing-masing 50\%. Median ini menunjukkan paro hidup literatur pada bidang yang bersangkutan (Hartinah, 2002:2).

Berdasarkan hasil penelitian yang dimuat dalam American Documentation (1960:20), paro hidup untuk ilmu teknik kimia 4,8 tahun; teknik mesin 5,2 tahun; matematika 10,5 tahun; fisika 4,6 tahun; kimia 8,1 tahun; geologi 11,8 tahun; fisiologi 7,2 tahun dan botani 10 tahun. Sebagai contoh, paro hidup ilmu fisika adalah 4,6 tahun. Apabila suatu dokumen penelitian fisika menggunakan rujukan berusia lebih dari 4,6 tahun dapat dikatakan bahwa referensi yang digunakan telah usang dan hal ini menunjukan adanya kemiskinan informasi, sebaliknya apabila rujukannya berusia kurang dari atau sama dengan 4,6 tahun dapat dikatakan bahwa referensi yang digunakan mutakhir dan hal ini menunjukan adanya kekayaan informasi.

\section{Pertumbuhan Literatur}

Paro hidup menunjukkan kecepatan pertumbuhan literatur, dengan sendirinya pertumbuhan ilmu, sehingga semakin muda usia paro hidup sebuah dokumen bidang ilmu, semakin cepat pertumbuhan ilmu tersebut (Sulistyo-Basuki, 2004:79-80).

Sebagai contoh paro hidup ilmu teknik kimia 4,8 tahun sedangkan geologi 11,8 tahun, berarti bahwa pertumbuhan literatur ilmu teknik kimia lebih cepat daripada literatur geologi. Bila dalam teknik kimia, peneliti menggunakan literatur yang berusia katakanlah 6 tahun, maka literatur tersebut sudah dianggap usang sementara dalam bidang geologi masih dianggap baru.

\section{METODE PENELITIAN}

Penelitian ini merupakan penelitian deskriptif dengan maksud untuk menggambarkan jenis literatur dan literatur yang dominan disitir, bahasa literatur, ketersediaan literatur dan keusangan literatur yang disitir dalam skripsi Jurusan Manajemen Hutan Fakultas Kehutanan UGM tahun 2008.

Menurut Arikunto (1998 : 310 ) penelitian deskriptif merupakan penelitian yang dimaksudkan untuk mengumpulkan informasi mengenai status suatu gejala yang ada, yaitu keadaan gejala menurut apa adanya pada saat penelitian dilakukan. Penelitian deskriptif tidak dimaksudkan untuk menguji hipotesis tertentu, tetapi hanya menggambarkan "apa adanya" tentang sesuatu variabel, gejala atau keadaan.

Populasi atau subjek penelitian ini adalah skripsi Jurusan Manajemen Hutan Fakultas Kehutanan UGM tahun 2008 yang berjumlah 67. Selain pertimbangan waktu dan biaya, pemilihan skripsi Jurusan Manajemen Hutan, didasarkan bahwa pada tahun 2008 jurusan Manajemen Hutan paling banyak meluluskan mahasiswa, sehingga jumlah skripsinya paling banyak. Disamping itu perkembangan ilmu manajemen hutan lebih pesat dibanding dengan jurusan lain.

Pada penelitian ini yang menjadi obyek penelitian adalah literatur yang disitir yang tercantum dalam daftar pustaka skripsi Jurusan Manajemen Hutan Fakultas Kehutanan UGM tahun 2008.

Metode pengumpulan data yang digunakan 
dalam penelitian ini adalah metode dokumentasi. Metode dokumentasi yaitu cara memperoleh data yang bersumber pada dokumen atau tulisan (Arikunto, 1998: 158). Pada penelitian ini dokumen yang akan diperiksa adalah skripsi Jurusan Manajemen Hutan Fakultas Kehutanan UGM tahun 2008.

Adapun tahap-tahap yang akan dilakukan penulis dalam pengumpulan data adalah sebagai berikut :

1. Mencari data ke Perpustakaan Fakultas Kehutanan UGM, skripsi Jurusan Manajemen Hutan tahun 2008. Mencatat nomor panggilnya.

2. Mengambil skripsi dari susunan rak berdasarkan nomor panggil skripsi tersebut.

3. Membuat Fotokopi daftar pustaka dan halaman sampul dari setiap skripsi

4. Setelah data terkumpul, selanjutnya dibuatkan lembar kerja dalam bentuk tabel menggunakan program Microsoft Excel. Kolom-kolom yang diperlukan pada tabel meliputi nomor, penulis skripsi, judul rujukan, pengarang, tahun terbit, tempat terbit, penerbit, jenis literatur, bahasa literatur, nama jurnal dan alamat internet . Selanjutnya data sitiran dimasukkan ke kolom pengisian data skripsi.

5. Membuat tabel yang terdiri dari 6 kolom, yaitu nomor, judul, pengarang, tahun terbit, frekuensi sitiran dan ketersediaan. Tabel ini digunakan untuk merinci data sitiran untuk masing-masing jenis literatur.

6. Membuat tabel yang terdiri dari 3 kolom, yang berisi nomor, judul dan tahun terbit. Tabel ini digunakan untuk menghitung usia literatur dan frekuensi tiap tahun terbit literatur.

7. Membuat tabel yang terdiri dari 3 kolom, yang berisi nomor, judul dan bahasa. Tabel ini digunakan untuk menghitung bahasa literatur yang disitir.

Setelah seluruh data terkumpul, maka peneliti melakukan analisis data dengan menggunakan prosentase. Tahapan yang dilakukan peneliti dalam menganalisis data untuk menjawab pertanyaan dalam penelitian adalah sebagai berikut :

1. Meneliti kelengkapan data yang telah diisi pada tabel lembar kerja Microsoft Excel.

2. Mengurutkan semua sitiran berdasarkan tahun terbit

3. Menentukan paro hidup literatur yang disitir mahasiswa
4. Menentukan keusangan literatur yang disitir pada skripsi Jurusan Manajemen Hutan Fakultas Kehutanan UGM tahun 2008. Paro hidup dapat dihitung dengan mengurutkan semua referensi yang diperlukan oleh semua dokumen pada masing-masing bidang mulai yang tertua (tahun terkecil) sampai yang terbaru (tahun terbesar) atau sebaliknya. Kemudian dicari median yang membagi daftar referensi yang sudah terurut tersebut menjadi 2 (dua) masing-masing $50 \%$. Median ini menunjukkan paro hidup literatur pada bidang yang bersangkutan (Hartinah, 2002:2).

5. Mengelompokkan data berdasarkan jenis literatur.

6. Menghitung jumlah sitiran yang diterima oleh masing-masing jenis literatur.

7. Penentuan peringkat jenis literatur yang paling sering disitir

8. Hasil penentuan peringkat jenis literatur dengan menggunakan prosentase dan disajikan dalam bentuk tabel.

9. Pengelompokkan berdasarkan jenis literatur akan terlihat jelas jenis literatur apa yang dominan disitir.

10. Mengelompokkan data berdasarkan bahasa literatur.

11. Penentuan peringkat bahasa literatur yang paling banyak disitir.

12. Hasil penentuan peringkat bahasa literatur dilakukan penghitungan prosentase dan disajikan dalam bentuk tabel.

13. Selanjutnya dari masing-masing tabel dilakukan analisis secara deskriptif.

14. Semua data sitiran dicocokkan dengan data koleksi di Perpustakaan Fakultas Kehutanan UGM melalui pangkalan data komputer untuk mengetahui keberadaannya di perpustakaan.

15. Dilakukan penghitungan koleksi yang tersedia dan tidak tersedia di perpustakaan.

16. Hasil penghitungan dipersentase dan disajikan dalam bentuk tabel.

Perhitungan persentase dalam penelitian ini menggunakan rumus dari Kerlinger (1995:246) yaitu :

$$
\text { Persentase }=\text { proporsi } \mathrm{X} 100
$$

Proporsi merupakan pecahan yang pembilangnya adalah satu diantara dua frekuensi atau lebih, sedangkan penyebutnya adalah jumlah 
seluruh frekuensi terobservasi. Adapun persentase hanyalah proporsi yang dikalikan 100 .

\section{HASIL PENELITIAN DAN PEMBAHASAN Jumlah Literatur yang Disitir}

Populasi penelitian ini adalah skripsi Jurusan Manajemen Hutan tahun 2008 sebanyak 67 skripsi. Masing-masing skripsi tersebut diambil datanya pada bagian daftar pustaka. Sebanyak 67 daftar pustaka yang terdapat pada seluruh skripsi tersebut, diperoleh jumlah literatur yang disitir sebanyak 1.498 sitiran.

\section{Keusangan Literatur}

Dalam menentukan keusangan literatur, penelitian ini menggunakan tipe diachronous. Tipe ini menggunakan paro hidup (half life) sebagai ukurannya. Penilaian paro hidup literatur dapat dilakukan dengan meneliti tahun terbitnya. Dalam mengukur paro hidup, penelitian ini tidak menggunakan jenis literatur terbitan pemerintah dan sumber internet karena terbitan pemerintah sudah jelas usia literaturnya, peraturan-peraturan yang dikeluărkan pemerintah otomatis tidak berlaku lagi apabila dikeluarkan peraturan baru. Sedangkan sumber internet merupakan salah satu sumber yang tidak direkomendasi untuk menjadi referensi dalam penulisan skripsi di fakultas Kehutanan UGM. Di samping itu sumber internet informasinya bersifat sementara, yang sewaktu-waktu dapat dihapus dari website. Dari data 1307 sitiran, ada 5 sitiran yang tidak terdapat tahun terbit literatur. Dengan demikian data yang dapat diolah 1302 sitiran. Langkah pertama yang harus dilakukan adalah mengurutkan tahun terbit literatur dari tahun terbit tertua ke tahun terbit termuda. Selanjutnya, menentukan usia literatur dan frekuensi sitiran tiap tahun terbit literatur. Selanjutnya untuk menghitung paro hidup literatur jumlah sitiran dibagi dalam kelompok 10 tahun, dapat dilihat pada tabel berikut ini.

Tabel 1

Sebaran Sitiran Menurut Kelompok Usia Sitiran

\begin{tabular}{cccc}
\hline $\begin{array}{c}\text { Kelompok Usia Sitiran } \\
\text { Dalam Tahun }\end{array}$ & $\begin{array}{c}\text { Frek. } \\
\text { Sitiran }\end{array}$ & $\%$ & $\%$ Kumulatif \\
\hline $121-130$ & 1 & 0.08 & 0.08 \\
$110-120$ & 0 & 0 & 0.08 \\
$100-110$ & 0 & 0 & 0.08 \\
$91-100$ & 0 & 0 & 0.08 \\
$81-90$ & 0 & 0 & 0.08 \\
$71-80$ & 0 & 0 & 0.08 \\
$61-70$ & 0 & 0 & 0.08 \\
$51-60$ & 15 & 1.15 & 1.23 \\
$41-50$ & 10 & 0.77 & 2 \\
$31-40$ & 70 & 5.38 & 7.38 \\
$21-30$ & 147 & 11.29 & 18.67 \\
$11-20$ & 283 & 21.73 & 40.4 \\
$0-10$ & 776 & 59.60 & 100 \\
\hline
\end{tabular}

Berdasarkan tabel 1 di atas literatur yang paling banyak digunakan oleh para mahasiswa dalam penulisan skripsi Jurusan Manajemen Hutan Fakultas Kehutanan UGM tahun 2008 adalah literatur yang terbit antara 1999-2008 atau yang berusia 0-10 tahun, yaitu 776 sitiran $(59,60 \%)$. Hal ini berarti nilai $50 \%$ berada pada kelompok usia 0 10 tahun. Hal ini menggambarkan bahwa peneliti telah menggunakan informasi yang relatif baru. Penghitungan paro hidup literatur adalah sebagai berikut:

$$
(100-100 / 2):(59,60: 10)
$$

$50: 5,96=8,39$ tahun dibulatkan 8 tahun.

Maka umur paro hidup literatur yang disitir pada skripsi mahasiswa jurusan Manajemen Hutan tahun 2008 adalah 8 tahun. Hal ini menunjukkan $50 \%$ dari literatur yang disitir pada skripsi mahasiswa jurusan Manajemen Hutan tahun 2008 berusia 8 tahun atau kurang, sedangkan $50 \%$ dari literatur yang disitir pada skripsi mahasiswa jurusan Manajemen Hutan tahun 2008 berusia lebih dari 8 tahun.

Dengan demikian dapat disimpulkan bahwa literatur yang berusia kurang atau sama dengan 8 tahun dikatakan mutakhir, sedangkan literatur yang berusia lebih dari 8 tahun dikatakan usang. Masih digunakannya literatur yang relatif tua, bahkan tahun 1884, kemungkinan karena informasi tersebut bersifat khusus. Karena informasi yang terkandung di dalamnya masih relevan untuk dipakai atau karena belum adanya penelitian sebidang yang dilakukan setelah tahun tersebut.

\section{Pertumbuhan Literatur}

Paro hidup menunjukkan kecepatan pertumbuhan literatur, dengan sendirinya pertumbuhan ilmu, sehingga semakin muda usia paro hidup sebuah dokumen bidang ilmu, semakin cepat pertumbuhan ilmu tersebut (Sulistyo-Basuki, 2004:79-80). Dari analisis sitiran dapat dihasilkan mengenai gambaran kecepatan pertumbuhan literatur berdasarkan jenis literatur yang disitir, bahasa literatur yang disitir, serta ketersediaan koleksi yang disitir di perpustakaan serta paro hidup literatur yang disitir.

Paro hidup literatur pada ilmu Manajemen Hutan Fakultas Kehutanan UGM menunjukkan 8 tahun. Hal ini berarti bahwa pertumbuhan literatur bidang Manajemen Hutan lebih cepat jika dibandingkan dengan pertumbuhan literatur bidang lain yang pernah diteliti dan dimuat dalam American Documentation (1960:20), seperti geologi 11,8 tahun, botani 10 tahun, dan matematika 10,5 tahun. 


\section{Jenis Literatur yang Disitir}

Jenis literatur dalam penelitian ini dikelompokkan atas buku, sumber internet, skripsi, jurnal/majalah, terbitan pemerintah, makalah, tesis, laporan penelitian, prosiding, disertasi, surat kabar dan tugas akhir. Sumber internet dalam penelitian ini dikelompokkan tersendiri karena informasi dari internet ini terkadang sulit untuk diidentifikasi apakah termasuk buku, jurnal/majalah maupun jenis literatur yang lain. Sumber internet bukan merupakan salah satu jenis literatur, tetapi merupakan salah satu jenis media untuk mengakses informasi. Hal ini dilakukan untuk menunjukkan seberapa banyak pemanfaatan sumber internet dalam penulisan skripsi mahasiswa Jurusan Manajemen Hutan tahun 2008. Adapun perolehan jumlah sitiran untuk masing-masing jenis literatur dapat dilihat pada tabel berikut ini.

Tabel 2

Jenis Literatur yang Disitir

\begin{tabular}{llcc}
\hline No & Jenis Literatur & Frekuensi Sitiran & $\%$ \\
\hline 1 & Buku & 950 & 63.42 \\
2 & Sumber Internet & 143 & 9.55 \\
3 & Skripsi & 130 & 8.68 \\
4 & Jurnal/Majalah & 111 & 7.41 \\
5 & Terbitan Pemerintah & 48 & 3.20 \\
6 & Makalah & 34 & 2.27 \\
7 & Tesis & 32 & 2.14 \\
8 & Laporan Penelitian & 26 & 1.74 \\
9 & Prosiding & 9 & 0.60 \\
10 & Disertasi & 8 & 0.53 \\
11 & Surat Kabar & 5 & 0.33 \\
11 & Tugas Akhir & 2 & 0.13 \\
\hline & \multicolumn{1}{c}{ Jumlah } & $\mathbf{1 4 9 8}$ & $\mathbf{1 0 0}$ \\
\hline
\end{tabular}

Berdasarkan tabel 2 dapat disimpulkan bahwa dari 1.498 sitiran dalam skripsi Jurusan Manajemen Hutan tahun 2008, buku merupakan jenis literatur yang paling banyak disitir, yaitu sebesar 950 sitiran $(63,42 \%)$, diikuti sumber internet 143 sitiran $(9,55$ $\%)$, skripsi 130 sitiran (8,68\%), jurnal/majalah 111 sitiran (7,41\%), terbitan pemerintah 48 sitiran $(3,20$ $\%$ ), makalah 34 sitiran (2,27\%), tesis 32 sitiran (2,14 $\%)$, laporan penelitian 26 sitiran (1,74\%), prosiding
9 sitiran $(0,60 \%)$, disertasi 8 sitiran $(0,53 \%)$, surat kabar 5 sitiran $(0,33 \%)$ dan tugas akhir 2 sitiran $(0,13 \%)$. Dominannya buku yang disitir, ternyata sesuai dengan ketersediaan koleksi buku yang memang lebih banyak dimiliki di perpustakaan Fakultas Kehutanan UGM jika dibandingkan dengan jenis literatur lainnya.

\section{Bahasa Literatur yang Disitir}

Berdasarkan hasil penelitian ini, ada 3 bahasa literatur yang disitir dalam skripsi Jurusan Manajemen Hutan tahun 2008 yaitu bahasa Indonesia, bahasa Inggris dan bahasa Jerman, dapat dilihat pada tabel 3 berikut ini:

Tabel 3

Bahasa Literatur yang Disitir

\begin{tabular}{crcc}
\hline No & Bahasa & Frekuensi Sitiran & $\%$ \\
\hline 1 & Indonesia & 1.328 & 88,65 \\
2 & Inggris & 169 & 11,28 \\
3 & Jerman & 1 & 0,07 \\
& Jumlah & $\mathbf{1 . 4 9 8}$ & $\mathbf{1 0 0}$ \\
\hline
\end{tabular}

Berdasarkan data dari tabel 3 di atas dapat diambil kesimpulan bahwa bahasa yang paling banyak disitir dalam skripsi Jurusan Manajemen Hutan tahun 2008 yaitu bahasa Indonesia sebanyak 1.328 sitiran $(88,65 \%$ ), diikuti bahasa Inggris 169 sitiran $(11,28 \%)$ dan bahasa Jerman 1 sitiran $(0,07$ $\%)$.

\section{Ketersediaan Koleksi}

Ketersediaan koleksi dapat diketahui dengan melakukan cross check dari data seluruh sitiran dengan data koleksi yang dimiliki perpustakaan. Berdasarkan data sitiran yang digunakan dalam penulisan skripsi mahasiswa Jurusan Manajemen Hutan tahun 2008 yang telah dicross check dengan data koleksi yang dimiliki perpustakaan diperoleh hasil bahwa 865 sitiran $(57,74 \%)$ tersedia di perpustakaan dan 633 sitiran $(42,26 \%)$ tidak tersedia di perpustakaan, dapat dilihat pada tabel 4 di bawah ini.

Tabel 4

Ketersediaan Literatur yang Disitir di Perpustakaan

\begin{tabular}{llcc}
\hline No & Ketersediaan & $\begin{array}{c}\text { Frekuensi } \\
\text { Sitiran }\end{array}$ & $\%$ \\
\hline 1 & Tersedia & 865 & 57,74 \\
2 & Tidak Tersedia & 633 & 42,26 \\
& Jumlah & $\mathbf{1 4 9 8}$ & $\mathbf{1 0 0}$ \\
\hline
\end{tabular}




\section{Ketersediaan Buku}

Buku merupakan jenis literatur yang paling banyak disitir yaitu sebesar 950 sitiran $(63,42 \%)$. Peringkat pertama dan kedua masing-masing 14 sitiran yaitu Pengusahaan hutan rakyat dan Politik kehutanan masyarakat, kemudian peringkat ketiga, keempat dan kelima masing-masing 10 sitiran yaitu Dekonstruksi sosial forestry : reposisi masyarakat dan keadilan lingkungan, metode inventore hutan dan metode penelitian, peringkat keenam dan ketujuh masing-masing 9 sitiran yaitu Hidrologi dan pengelolaan daerah aliran sungai dan Hutan rakyat : sosial ekonomi dan pemasaran, kemudian peringkat kedelapan, kesembilan dan kesepuluh masingmasing 8 sitiran yaitu Atlas kayu Indonesia, Konsepkonsep dasar sistem informasi geografis dan Metode penelitian bidang sosial.

Kemudian seluruh data sitiran dari buku dicrosscheck dengan koleksi buku yang dimiliki perpustakaan hasilnya 216 judul buku (449 sitiran) tersedia di perpustakaan dan 370 judul buku (501 sitiran) tidak tersedia di perpustakaan. Buku yang banyak memperoleh sitiran berarti buku tersebut penting bagi pemakai sehingga ketersediaannya di perpustakaan perlu diperhatikan.

\section{Ketersediaan Sumber Internet}

Sumber internet memberikan kemudahan dan keleluasaan bagi penulis maupun peneliti untuk memperoleh informasi. Beragam informasi yang dapat dijadikan sebagai sumber referensi dapat diakses dengan mudah sehingga mahasiswa dalam menyusun skripsi memanfaatkan informasi yang bersumber dari internet sebagai bahan untuk mendukung karyanya.

Hasil penelitian menunjukkan bahwa sumber internet merupakan peringkat kedua jenis literatur yang disitir dengan 143 sitiran $(9,55 \%)$. Perpustakaan Fakultas Kehutanan UGM menyediakan fasilitas layanan internet dan wifi areakepada pemakainya. Dengan demikian dalam penelitian ini sitiran yang bersumber internet ketersediaannya dapat dikatakan tersedia seluruhnya.

\section{Ketersediaan Skripsi}

Hasil penelitian menunjukkan bahwa skripsi berada pada peringkat ketiga dari jenis literatur yang disitir yaitu sebanyak 130 sitiran (8,68\%). Hasil penelitian menunjukkan bahwa skripsi yang disitir sebanyak 130 sitiran, 110 judul. Sebanyak 124 sitiran, terdiri atas 104 judul skripsi tersedia di perpustakaan dan 6 sitiran terdiri atas 6 judul tidak tersedia di perpustakaan. Judul skripsi yang memperoleh sitiran tertinggi yaitu Studi Kandungan Karbon pada Berbagai Organ Pohon Sengon dengan 6 sitiran.

\section{Ketersediaan Jurnal/Majalah}

Hasil penelitian menunjukkan bahwa penggunaan jurnal/majalah menduduki peringkat keempat dengan hasil sebanyak 111 sitiran $(7,41 \%)$. Dari 111 sitiran ditemukan 45 judul jurnal/majalah. Jurnal yang memperoleh sitiran tertinggi adalah Jurnal Hutan Rakyat dengan 16 sitiran, diikuti Duta Rimba dengan 12 sitiran, Jurnal Inovasi dengan 8 sitiran, Forest Research dan Gatra masing-masing 7 sitiran dan Jurnal Sosial Ekonomi Kehutanan dengan 6 sitiran. Jurnal Hutan Rakyat memperoleh sitiran tertinggi dan kebetulan jurnal tersebut diterbitkan oleh Jurusan Manajemen Hutan Fakultas Kehutanan UGM sehingga tersedia di perpustakaan.

Jurnal/majalah yang disitir sebanyak 111 sitiran dengan 45 judul. Sebanyak 75 sitiran terdiri atas 28 judul tersedia di perpustakaan dan 36 sitiran terdiri atas 17 judul tidak tersedia di perpustakaan. Tidak tersedianya jurnal di perpustakaan disebabkan ketersediaan jurnal bukan dari langganan tetapi sebatas tukar menukar.

\section{Ketersediaan Terbitan Pemerintah}

Terbitan pemerintah menempati peringkat kelima dari jenis literatur yang disitir. Terbitan pemerintah disitir sebanyak 48 sitiran $(3,20 \%)$. Hasil penelitian menunjukkan bahwa terbitan pemerintah memperoleh 48 sitiran dengan 27 judul. Sebanyak 18 sitiran terdiri atas 6 judul tersedia di perpustakaan dan sebanyak 30 sitiran terdiri atas 21 judul tidak tersedia di perpustakaan. Terbitan pemerintah yang memperoleh sitiran tertinggi yaitu Undang-undang No 41/1999 tentang Kehutanan dengan 12 sitiran.

\section{Ketersediaan Makalah}

Makalah menempati peringkat keenam dari jenis literatur yang disitir. Makalah disitir sebanyak 34 sitiran $(2,27 \%)$. Hasil penelitian menunjukkan bahwa makalah disitir sebanyak 34 sitiran dengan 26 judul. Dari 34 sitiran tersebut semuanya tidak tersedia di perpustakaan. Seperti kita ketahui makalah bukan bahan yang dapat diperoleh dengan cara membeli, sehingga dibutuhkan peran aktif pustakawan untuk mendapatkannya. 


\section{Ketersediaan Tesis}

Tesis menempati peringkat ketujuh dari jenis literatur yang disitir. Tesis disitir sebanyak 32 sitiran $(2,14 \%)$. Hasil penelitian menunjukkan bahwa tesis disitir sebanyak 32 sitiran dengan 21 judul. Sebanyak 26 sitiran terdiri atas 15 judul tersedia di perpustakaan dan 6 sitiran terdiri atas 6 judul tidak tersedia di perpustakaan. Judul tesis yang paling sering disitir adalah Studi Produksi Biomassa dan Kemampuan Tegakan Sengon di Hutan Rakyat dalam Mengurangi Akumulasi CO2 di Udara yang ditulis oleh Woesono disitir sebanyak 7 kali.

\section{Ketersediaan Laporan Penelitian}

Laporan penelitian menduduki peringkat kedelapan dari jenis literatur yang disitir oleh mahasiswa. Laporan penelitian yang disitir sebanyak 26 sitiran $(1,74 \%)$. Hasil penelitian menunjukkan bahwa laporan penelitian memperoleh sitiran sebanyak 26 sitiran dengan 21 judul. Sebanyak 14 sitiran yang terdiri dari 12 judul tersedia di perpustakaan dan 12 sitiran terdiri dari 9 judul tidak tersedia di perpustakaan. Dari 9 judul yang tidak tersedia di perpustakaan sebanyak 7 judul merupakan laporan penelitian yang dilakukan peneliti dari luar Fakultas Kehutanan UGM yang terdiri dari Balai Penelitian dan Pengembangan Daerah Aliran Sungai Indonesia Bagian Barat (BP2TPDAS-IBB) Surakarta, Tim Peneliti Universitas Kristen Satya Wacana Salatiga, Dinas Lingkungan Hidup Kota Yogyakarta, Badan Koordinasi Survei dan Pemetaan Nasional, Lembaga Penelitian IPB dan Fakultas Isipol UGM.

Sedangkan 2 judul lainnya yang tidak tersedia di perpustakaan merupakan laporan penelitian yang ditulis oleh staf pengajar Fakultas Kehutanan UGM. Tidak tersedianya laporan penelitian yang disusun oleh staf pengajar Fakultas Kehutanan UGM disebabkan karena tidak adanya kewajiban staf pengajar yang melaksanakan kegiatan penelitian untuk menyerahkan hasil penelitiannya atau laporan penelitiannya ke perpustakaan.

\section{Ketersediaan Prosiding}

Prosiding menempati peringkat kesembilan dari jenis literatur yang disitir. Prosiding disitir sebanyak 9 sitiran $(0,60 \%)$. Sebanyak 7 sitiran yang terdiri atas 4 judul tersedia di perpustakaan dan 2 judul yang masing-masing disitir 1 kali tidak tersedia di perpustakaan. Judul prosiding yang sering disitir yaitu Proceedings seminar daur jati tanggal 5 Januari 1985, disitir sebanyak 3 kali.

\section{Ketersediaan Disertasi}

Disertasi menempati peringkat kesepuluh dari jenis literatur yang disitir. Disertasi disitir sebanyak 8 sitiran $(0,53 \%)$. Judul yang paling banyak disitir yaitu Dimensi Pohon dan Perkembangan Metode Pendugaan Volume Pohon yang ditulis oleh Muhdin disitir sebanyak 5 kali. Disertasi ini diterbitkan oleh Program Pascasarjana IPB sehingga tidak tersedia di perpustakaan.

\section{Ketersediaan Surat Kabar}

Surat kabar menempati peringkat kesebelas dari jenis literatur yang disitir. Surat kabar disitir sebanyak 5 sitiran $(0,33 \%)$. Surat kabar yang disitir terdiri atas Kedaulatan Rakyat disitir 2 kali, Kompas disitir 2 kali dan Antara News disitir 1 kali.

\section{Ketersediaan Tugas Akhir}

Tugas akhir menempati peringkat keduabelas dari jenis literatur yang disitir. Tugas akhir memperoleh sitiran paling rendah kemungkinan karena penelitian ini menganalisis sitiran terhadap skripsi. Tugas akhir disitir sebanyak 2 sitiran $(0,13$ \%) dengan 1 judul. Judul Tugas Akhir yang disitir adalah Persepsi Masyarakat Desa Hutan terhadap Pengelolaan Hutan Kemasyarakatan yang ditulis oleh Prastiyanto.

\section{KESIMPULAN}

Berdasarkan analisis dan pembahasan yang telah dilakukan terhadap evaluasi literatur dengan menggunakan analisis sitiran terhadap skripsi Jurusan Manajemen Hutan tahun 2008 di Perpustakaan Fakultas Kehutanan UGM, maka diperoleh beberapa kesimpulan sebagai berikut :

1. Keusangan literatur yang digunakan pada skripsi mahasiswa jurusan Manajemen Huten tahun 2008 adalah literatur yang berusia kurang atau sama dengan 8 tahun dikatakan mutakhir sedangkan literatur yang berusia lebih dari 8 tahun dikatakan sudah usang.

2. Pertumbuhan literatur pada penelitian ini menunjukkan 8 tahun, berarti bahwa pertumbuhan literatur bidang Manajemen Hutan cukup cepat jika dibandingkan dengan ilmu lain seperti geologi 11,8 tahun, botani 10 tahun, matematika 10,5 tahun. Pertumbuhan literatur berdasarkan jenis literatur dan bahasa literatur yang disitir menunjukkan bahwa buku merupakan jenis literatur yang paling banyak disitir dengan 950 sitiran $(63,42 \%)$. 
Dominannya buku yang disitir ternyata sesuai dengan ketersediaan buku yang memang paling banyak dimiliki perpustakaan Fakultas Kehutanan UGM. Bahasa literatur yang paling banyak disitir adalah literatur berbahasa Indonesia dengan 1.328 sitiran $(88,65 \%)$.

3. Literatur yang disitir dan tersedia di perpustakaan sebanyak 865 sitiran atau $57,74 \%$ dan sebanyak 633 sitiran atau 42,26\% literatur yang disitir tidak tersedia di perpustakaan.

\section{DAFTAR PUSTAKA}

Arikunto, Suharsimi. Manajemen Penelitian. Jakarta: PT Rineka Cipta, 1998.

Arikunto, Suharsimi. Prosedur Penelitian Suatu Pendekatan Praktik. Jakarta : PT Rineka Cipta, 1998.

Evans, G.E. Developing Library and Information Center Collections. $4^{\text {th }}$ ed. Colorado : Libraries Unlimited. 2000.

Hartinah, S. "Analisis Sitiran (Citation Analysis)". Dalam Kumpulan Makalah Kursus Bibliometrika. Depok : Masyarakat Infometrika Indonesia. 2002.

Hasugian, J. "Analisis Sitiran terhadap Disertasi Program Doktor (S-3) Ilmu Kedokteran Sekolah Pascasarjana Universitas Sumatera Utara", Dalam Pustaka : Jurnal Studi Perpustakaan dan Informasi, Volume 1, Nomor 2, 2005.

Jamasri. Metodologi Riset. Jurusan Teknik Mesin Fakultas Teknik Universitas Gadjah Mada Yogyakarta. 2004

Kerlinger, Fred N. Asas-asas Penelitian Behavioral. Yogyakarta : Gadjah Mada University Press. 1995.

Nawawi, H. Metode Penelitian Bidang Sosial. Yogyakarta : Gadjah Mada University Press. 1985.

Nazir, M. Metode Penelitian. Jakarta : Ghalia Indonesia. 1988
Qalyubi, Syihabuddin. dkk. Dasar-Dasar Ilmu Perpustakaan dan Informasi. Yogyakarta: Fakultas Adab, UIN Sunan Kalijaga, 2007.

Rahayuningsih, F. Pengelolaan Perpustakaan. Yogyakarta : Graha Ilmu. 2007

Sujana, Janti G. 2006. Mengoptimumkan Pengembangan Koleksi. Dalam Buletin Perpustakaan dan Informasi Bogor Vol I No 5. Dalam http://bpib-art.blogspot.com/ 2006/10/mengoptimumkan -pengembangankoleksi.html diakses tanggal 6 April 2009 pukul 10.15 WIB

Sulistyo-Basuki. 1988. Bahan Pengajaran: Pengantar Ilmu Informasi. Jakarta : Pusat antar Universitas Ilmu Komputer Universitas Indonesia, 1988.

- Pengantar Ilmu Perpustakaan. Jakarta : Gramedia Pustaka Utama, 1991. - Analisis Sitiran, Kositiran dan Pasangan Bibliografis (Citation Analysis, CoCitation, dan Bibliographic Coupling). Dalam Sosok Pribadi Unik Mastini Hardjoprakosa. Mochtar, K. Dkk (Ed). Jakarta : Yayasan Kawedi, 1994.

Bibliometrika, Sainsmetrika dan Informetrika. Dalam Kumpulan Makalah Kursus Bibliometrika. Depok : Masyarakat Infometrika Indonesia, 2002.

:Rekayasa Sains. 2004.

Zulaikha, Sri Rohyanti. "Kajian Analisis Sitiran Terhadap Skripsi Mahasiswa IAIN Sunan Kalijaga di UPT Perpustakaan IAIN Sunan Kalijaga Yogyakarta (Suatu Evaluasi Keterpakaian Koleksi Perpustakaan Ditinjau dari Analisis Sitiran)". (tesis). Program Pascasarjana, Universitas Gadjah Mada Yogyakarta. 2002. 